\title{
Two new stemphol sulfates from the mangrove endophytic fungus Stemphylium sp. 33231
}

\author{
Xue-Ming Zhou ${ }^{1}$, Cai-Juan Zheng ${ }^{1}$, Guang-Ying Chen, Xiao-Ping Song, Chang-Ri Han, Xiong-Zhao Tang, \\ Rui-Jie Liu and Li-Lian Ren \\ Two new stemphol sulfates, stemphol A (1) and stemphol B (2), along with known compound stemphol (3) were isolated from \\ the EtOAc extract of the fermentation of an endophytic Stemphylium sp. 33231. The structures of these compounds were \\ elucidated on the basis of spectroscopic analysis. The isolated compounds exhibited potent antibacterial activities against six \\ terrestrial pathogenic bacteria with MIC values of $0.6-10 \mu \mathrm{g} \mathrm{ml}^{-1}$. The inhibitory activities of all compounds against five cancer \\ cell lines were evaluated.
}

The Journal of Antibiotics (2015) 68, 501-503; doi:10.1038/ja.2015.16; published online 25 February 2015

\section{INTRODUCTION}

Endophytic fungi of the genus Stemphylium are a rich source of bioactive secondary metabolites with diverse structures. ${ }^{1-4}$ Our group recently reported the isolation of two new $\alpha$-pyrone derivatives, infectopyrones $\mathrm{A}$ and $\mathrm{B},{ }^{5}$ as well as four new anthraquinone derivatives, auxarthrol C, 2-O-acetyl-altersolanol B, 2-O-acetyl-altersolanol L and macrosporin-2-O-(6'-acetyl)- $\alpha$-D-glucoside. Four new alterporriol-type anthranoid dimers, alterporriols $\mathrm{T}-\mathrm{W}$ from the Stemphylium sp. 33231, were also reported. ${ }^{6}$ In our ongoing investigation of natural antibacterial and cytotoxic products, two new unusual phenolic sulfates, stemphol A (1) and stemphol B (2), along with known compound stemphol (3) (Figure 1) were isolated from the potato glucose liquid fermentation broth of Stemphylium sp. 33231. Phenolic sulfate derivatives isolated from microorganisms are uncommon. Only panosialin as a phenolic sulfate derivative was isolated from Streptomyces. ${ }^{7,8}$ Herein we report the isolation, structure elucidation and biological activities of these compounds (1-3).

\section{RESULTS AND DISCUSSION}

Isolation and identification of compounds

Compound 1 was isolated as a white powder. The high-resolution electrospray ionization mass spectrometry (HRESIMS) exhibited ion peaks at $m / z 361.1066[\mathrm{M}+\mathrm{Na}]^{+}$and $315.1263[\mathrm{M}-\mathrm{Na}]^{-}$, indicating a molecular formula of $\mathrm{C}_{15} \mathrm{H}_{23} \mathrm{O}_{5} \mathrm{SNa}$. The presence of sulfate was confirmed by the characteristic loss of $102 \mathrm{amu}$ at $\mathrm{m} / \mathrm{z} 259.1673$ [M $\left.+\mathrm{Na}-\mathrm{SO}_{3} \mathrm{Na}+\mathrm{H}\right]^{+}$. In the ${ }^{1} \mathrm{H}$ NMR (Table 1 ) spectrum, one hydroxy group at $\delta_{\mathrm{H}} 8.02(\mathrm{~s})$, two meta-coupled aromatic proton groups at $\delta_{\mathrm{H}}$ $6.94(\mathrm{~d}, J=1.2 \mathrm{~Hz})$ and $6.48(\mathrm{~d}, J=1.2 \mathrm{~Hz})$, seven methylene groups and two methyl groups were observed. A combined analysis of the ${ }^{13} \mathrm{C}$ NMR (Table 1) and DEPT spectra revealed 15 resonances including six olefinic carbons $\left(\delta_{\mathrm{C}} 156.3,153.2,141.0,119.9,113.6\right.$ and 111.6), seven methylene carbons $\left(\delta_{\mathrm{C}} 36.4,32.4,32.3,31.8,24.2,23.6\right.$ and 23.2) and two methyl carbons $\left(\delta_{\mathrm{C}} 14.4\right.$ and 14.3$)$. These ${ }^{1} \mathrm{H}$ and ${ }^{13} \mathrm{C}$ NMR data indicated that a hydroxy group in resorcinol with two short unbranched chains was replaced by a sulfate group for 1 . This assignment was confirmed by the following HMBC correlation data. The HMBC correlations from H-8 to C-7, C-9 and C-10 (Figure 2) indicated that the short branched chain consists of three methylene carbons and one methyl carbon. Therefore, the other short branched chain consists of four methylene carbons and one methyl carbon. Next, we found that the structure of $\mathbf{1}$ was very similar to 3 , except for the extra signals $\left(\delta_{\mathrm{C}} 153.2,111.6\right.$ and $\delta_{\mathrm{H}}$ 6.94) in 1 . These characteristics implied that a hydroxy group in 3 was replaced by a sulfate group for $\mathbf{1}$, generating the extra two olefinic carbon signals in 1. Furthermore, the sulfate group at this position was confirmed by the upfield-shifted resonances of C-1 $\left(\delta_{\mathrm{C}} 153.2\right)$ relative to C-3 $\left(\delta_{\mathrm{C}}\right.$ 156.3). Thus, the structure of 1 was identified as shown in Figure 1. Compound 1 was named as stemphol A.

Compound 2 was also isolated as a white powder. The HRESIMS exhibited ion peaks at $m / z 403.1165[\mathrm{M}+\mathrm{Na}]^{+}$and $357.1375[\mathrm{M}-\mathrm{Na}]^{-}$, indicating a molecular formula of $\mathrm{C}_{17} \mathrm{H}_{25} \mathrm{O}_{6} \mathrm{SNa}$. The ${ }^{1} \mathrm{H}$ and ${ }^{13} \mathrm{C}$ NMR data (Table 1) of 2 resembled those of $\mathbf{1}$, except for the disappearance of a hydroxy signal at $\delta_{\mathrm{H}} 8.02(\mathrm{~s})$ in $\mathbf{1}$ and the presence of an acetoxy group $\left(\delta_{\mathrm{C}} 169.7,20.8\right.$ and $\left.\delta_{\mathrm{H}} 2.26, \mathrm{~s}\right)$ in 2 . These characteristics implied that the hydroxy group in $\mathbf{1}$ was replaced by an acetoxy group in 2 . Further confirmation was achieved by the observed HMBC correlations of H-Ac to C-3 (this is a weak signal) (Figure 2). Detailed analysis of 2D NMR (HSQC, ${ }^{1} \mathrm{H}-{ }^{1} \mathrm{H}$ COSY and HMBC) spectra confirmed that the other parts of the molecule were the same as those of $\mathbf{1}$. Thus, the structure of $\mathbf{2}$ was identified as stemphol B. 
<smiles>[R9]c1cc(C(=C)CCCC)cc([N+]([O])([O-])O[Na])c1CCCC</smiles>

$1 \mathrm{R}=\mathrm{H} \quad 2 \mathrm{R}=\mathrm{Ac}$

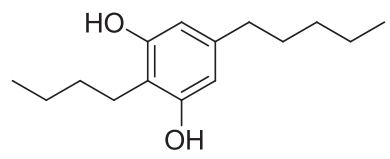

3
Figure 1 The structure of compounds $\mathbf{1}-\mathbf{3}$.

Table 1 NMR data for compounds 1,2 and 3

\begin{tabular}{|c|c|c|c|c|c|c|}
\hline \multirow[b]{2}{*}{ Position } & \multicolumn{2}{|c|}{1 (in Acetone- $d_{6}$ ) } & \multicolumn{2}{|c|}{2 (in Acetone- $d_{6}$ ) } & \multicolumn{2}{|c|}{3 (in Acetone- $d_{6}$ ) } \\
\hline & $\delta_{H}$ & $\delta_{C}$ & $\delta_{H}$ & $\delta_{C}$ & $\delta_{H}$ & $\delta_{C}$ \\
\hline 1 & - & $153.2, \mathrm{C}$ & - & $153.4, \mathrm{C}$ & - & 156.7, C \\
\hline 2 & - & 119.9, C & - & 125.6, C & - & $113.8, \mathrm{C}$ \\
\hline 3 & - & $156.3, \mathrm{C}$ & - & $150.4, C$ & - & 156.7, C \\
\hline 4 & $\begin{array}{c}6.48 \mathrm{~d} \\
(1.2)\end{array}$ & $111.6, \mathrm{CH}$ & $\begin{array}{c}6.25 \mathrm{~d} \\
(1.6)\end{array}$ & $118.4, \mathrm{CH}$ & $6.22 \mathrm{~s}$ & 107.6, CH \\
\hline 5 & - & 141.0, C & - & $141.5, \mathrm{C}$ & - & 141.7, C \\
\hline 6 & $\begin{array}{c}6.94 \mathrm{~d} \\
(1.2)\end{array}$ & $113.6, \mathrm{CH}$ & $\begin{array}{c}7.32 \mathrm{~d} \\
(1.6)\end{array}$ & 119.7, CH & $6.22 \mathrm{~s}$ & 107.6, CH \\
\hline 7 & $\begin{array}{c}2.68 \mathrm{t} \\
(7.6)\end{array}$ & $24.2, \mathrm{CH}_{2}$ & $\begin{array}{c}2.57 \mathrm{t} \\
(7.6)\end{array}$ & $24.8, \mathrm{CH}_{2}$ & $\begin{array}{c}2.61 \mathrm{t} \\
(8.0)\end{array}$ & $23.5, \mathrm{CH}_{2}$ \\
\hline 8 & $1.50 \mathrm{~m}$ & $32.3, \mathrm{CH}_{2}$ & $1.48 \mathrm{~m}$ & $32.2, \mathrm{CH}_{2}$ & $1.49 \mathrm{~m}$ & $32.2, \mathrm{CH}_{2}$ \\
\hline 9 & $1.33 \mathrm{~m}$ & 23.6, $\mathrm{CH}_{2}$ & $1.33 \mathrm{~m}$ & $23.5, \mathrm{CH}_{2}$ & $1.37 \mathrm{~m}$ & $23.4, \mathrm{CH}_{2}$ \\
\hline 10 & $\begin{array}{c}0.88 \mathrm{t} \\
(7.2)\end{array}$ & $14.3, \mathrm{CH}_{3}$ & $\begin{array}{c}0.89 \mathrm{t} \\
(7.2)\end{array}$ & $14.2, \mathrm{CH}_{3}$ & $\begin{array}{c}0.90 \mathrm{t} \\
(7.2)\end{array}$ & $14.3, \mathrm{CH}_{3}$ \\
\hline 11 & $\begin{array}{c}2.42 \mathrm{t} \\
(7.6)\end{array}$ & $36.4, \mathrm{CH}_{2}$ & $\begin{array}{c}2.53 \mathrm{t} \\
(7.6)\end{array}$ & $36.1, \mathrm{CH}_{2}$ & $\begin{array}{c}2.38 \mathrm{t} \\
(8.0)\end{array}$ & $36.2, \mathrm{CH}_{2}$ \\
\hline 12 & $1.55 \mathrm{~m}$ & $31.8, \mathrm{CH}_{2}$ & $1.58 \mathrm{~m}$ & $31.7, \mathrm{CH}_{2}$ & $1.54 \mathrm{~m}$ & 31.7, $\mathrm{CH}_{2}$ \\
\hline 13 & $1.30 \mathrm{~m}$ & $32.4, \mathrm{CH}_{2}$ & $1.33 \mathrm{~m}$ & $32.3, \mathrm{CH}_{2}$ & $1.33 \mathrm{~m}$ & $32.3, \mathrm{CH}_{2}$ \\
\hline 14 & $1.28 \mathrm{~m}$ & 23.1, $\mathrm{CH}_{2}$ & $1.30 \mathrm{~m}$ & 23.2, $\mathrm{CH}_{2}$ & $1.28 \mathrm{~m}$ & 23.2, $\mathrm{CH}_{2}$ \\
\hline 15 & $\begin{array}{c}0.88 \mathrm{t} \\
(7.2)\end{array}$ & $14.4, \mathrm{CH}_{3}$ & $\begin{array}{c}0.87 \mathrm{t} \\
(7.2)\end{array}$ & $14.3, \mathrm{CH}_{3}$ & $\begin{array}{c}0.87 \mathrm{t} \\
(7.2)\end{array}$ & $14.4, \mathrm{CH}_{3}$ \\
\hline Ac-Me & - & - & $2.26 \mathrm{~s}$ & $20.8, \mathrm{CH}_{3}$ & & \\
\hline$A c-C=0$ & - & - & - & 169.7, C & - & \\
\hline $3-\mathrm{OH}$ & $8.02 \mathrm{~s}$ & & & & & \\
\hline
\end{tabular}
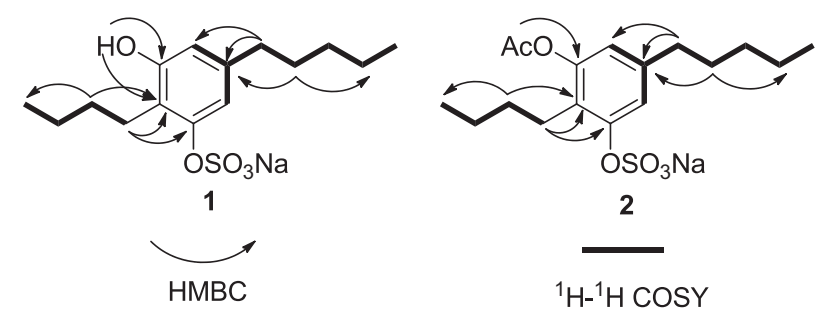

Figure 2 Key partial structures of compounds 1 and 2 from $\mathrm{HMBC}$ data and ${ }^{1} \mathrm{H}-{ }^{1} \mathrm{H}$ COSY.

The structure of known 3 was identified by comparison of its ${ }^{1} \mathrm{H} /{ }^{13} \mathrm{C}$ NMR spectra with those in the literature. ${ }^{9-12}$

\section{Biological properties of stemphol A and B}

The antibacterial activities of all the compounds were determined against six terrestrial pathogenic bacteria Micrococcus tetragenus (ATCC 13623), Escherichia coli (ATCC 25922), Bacillus cereus (ATCC
Table 2 Antibacterial activity for compounds 1, 2 and 3

\begin{tabular}{lcccccc}
\hline & \multicolumn{6}{c}{$M I C\left(\mu g l^{-1}\right)$} \\
\cline { 2 - 7 } Compound & S. aureus & E. coli & B. subtilis & M. tetragenus & K. rhizophila & B. cereus \\
\hline $\mathbf{1}$ & 10.0 & 5.0 & $>10.0$ & 10.0 & 5.0 & 5.0 \\
$\mathbf{2}$ & 1.25 & 0.6 & 2.5 & 1.25 & 1.25 & 0.6 \\
$\mathbf{3}$ & 5.0 & 0.6 & 2.5 & 1.25 & 2.5 & 5.0 \\
Ciprofloxacin $^{\text {a }}$ & 0.6 & 0.3 & 0.6 & 0.3 & 0.3 & 0.3 \\
\hline
\end{tabular}

${ }^{\mathrm{a} C i p r o f l o x a c i n}$ was used as a positive control.

14579), Staphylococcus aureus (ATCC 8799), Kocuria rhizophila (ATCC 9341) and Bacillus subtilis (ATCC 6633). Compounds $\mathbf{1}-\mathbf{3}$ exhibited broad-spectrum antibacterial activites against these bacterias (Table 2). Compound 2 exhibited especially potent antibacterial activites against E. coli and B. cereus with MIC values of $0.6 \mu \mathrm{g} \mathrm{mlL}^{-1}$. All compounds were evaluated for cytotoxic activities against the human promyelocytic leukemia cell line (HL-60), the human hepatocarcinoma cell line (SMMC-7721), human lung carcinoma cell line (A-549), human breast adenocarcinoma cell line (MCF-7) and human colorectal cancer cell line (SW480). However, no significant cytotoxic activities against the five cancer cell lines were observed at $40 \mu \mathrm{M}$.

\section{METHODS}

\section{Fungal materials}

The fungal strain Stemphylium sp. 33231 was isolated from the fresh healthy leaf of Brguiera sexangula var. rhynchopetala collected in the South China Sea in August, 2012. The fungal strain was deposited in the Key Laboratory of Tropical Medicinal Plant Chemistry of Ministry of Education, College of Chemistry and Chemical Engineering, Hainan Normal University of PR China, Hainan with an accession number KF479349. ${ }^{5}$ The strain was grown in 301 of liquid potato glucose liquid medium ( $15 \mathrm{~g}$ of glucose and $30 \mathrm{~g}$ of sea salt in 11 of potato infusion, in 1-1 Erlenmeyer flasks each containing $300 \mathrm{ml}$ of culture broth) at room temperature under static conditions for 28 days.

\section{General experimental procedures}

Octadecylsilyl silica gel (YMC, Kyoto, Japan; $12 \mathrm{~nm}-50 \mu \mathrm{m}$ ), silica gel (Qing Dao Hai Yang Chemical Group Co., Qing Dao, China; 200-300 mesh) and Sephadex LH-20 (GE) were used for column chromatography (CC). Precoated silica gel plates (Yan Tai Zi Fu Chemical Group Co., Yantai, China; G60, F-254) were used for TLC. ${ }^{1} \mathrm{H}$ and ${ }^{13} \mathrm{C}$ NMR spectra were recorded on a Bruker AV spectrometer (Bruker, Zurich, Switzerland) at 400 and $100 \mathrm{MHz}$ in acetone- $\mathrm{d}_{6}$. Chemical shifts $\delta$ are reported in ppm, using tetramethylsilane (TMS) as internal standard, and coupling constants $(J)$ are in Hz. HRESIMS spectra were measured on a Q-TOF Ultima Global GAA076 LC mass spectrometer (Waters Asia, Ltd, Singapore). UV spectra were recorded on a Beckman DU 640 spectrophotometer (Brea, CA, USA). IR spectra were recorded on a Nicolet 6700 spectrophotometer (Thermo Fisher Scientific Co., Waltham, MA, USA).

\section{Extraction and isolation}

The fungal cultures were filtered through cheesecloth, and the filtrate was extracted with EtOAc $(3 \times 301,10 \mathrm{~h}$ each $)$. The EtOAc extracts were concentrated in vacuo to yield an oily residue (25.2 g), which was subjected to silica-gel CC (petroleum ether/EtOAc v/v, 100:0-0:100) to generate five fractions (Fr. 1Fr. 5). Fr. 1 was isolated by CC on silica gel eluted with petroleum ether:EtOAc (20:1) and further purified by using Sephadex LH-20 CC, eluting with mixtures of petroleum $\mathrm{CHCl}_{3}: \mathrm{MeOH}(1: 1)$ to obtain compound 3 (10.2 mg). Fr. 5 was isolated by CC on silica gel eluted with petroleum MeOH:EtOAc (1:10) and then subjected to Sephadex LH-20 CC, eluting with mixtures of petroleum 
$\mathrm{CHCl}_{3}: \mathrm{MeOH}(1: 1)$, and further purified by using octadecylsilyl silica gel eluted with $30 \% \mathrm{MeOH} / \mathrm{H} 2 \mathrm{O}$ to obtain compounds $1(25.0 \mathrm{mg})$ and $2(11.2 \mathrm{mg})$.

\section{Physical properties of compounds 1 and 2}

Stemphol A (1): white power; UV (MeOH) $\lambda_{\max }(\log \varepsilon) 273$ (2.22), 239 (1.26) nm; IR (KBr) $\nu_{\max } 3324,2927,1627,1435$ and $1208 \mathrm{~cm}^{-1}$; ${ }^{1} \mathrm{H}$ and ${ }^{13} \mathrm{C}$ NMR: see Table 1; HRESIMS $\mathrm{m} / \mathrm{z} 361.1066[\mathrm{M}+\mathrm{Na}]^{+}$(calcd for $\mathrm{C}_{15} \mathrm{H}_{23} \mathrm{O}_{5} \mathrm{SNa}_{2}$, 361.1062), 315.1263 [M-Na] ${ }^{-}$(calcd for $\mathrm{C}_{15} \mathrm{H}_{23} \mathrm{O}_{5} \mathrm{~S}, 315.1266$ ).

Stemphol B (2): white power; UV $(\mathrm{MeOH}) \lambda_{\max }(\log \varepsilon) 278$ (2.82), 249 (1.44) nm; IR (KBr) $\nu_{\max } 3468,2930,1732,1624,1398$ and $1168 \mathrm{~cm}^{-1} ;{ }^{1} \mathrm{H}$ and ${ }^{13} \mathrm{C}$ NMR: see Table 1; HRESIMS $\mathrm{m} / \mathrm{z} 403.1165[\mathrm{M}+\mathrm{Na}]^{+}$(calcd for $\mathrm{C}_{17} \mathrm{H}_{25} \mathrm{O}_{6} \mathrm{SNa}_{2}, \quad 403.1167$ ), $357.1375[\mathrm{M}-\mathrm{Na}]^{-}$(calcd for $\mathrm{C}_{17} \mathrm{H}_{25} \mathrm{O}_{6} \mathrm{~S}$, 357.1372).

\section{Biological assays}

Cytotoxic activity was tested by the MTT method as described previously. ${ }^{13}$ Five cancer cell lines, the human promyelocytic leukemia cell line (HL-60), the human hepatocarcinoma cell line (SMMC-7721), human lung carcinoma cell line (A-549), human breast adenocarcinoma cell line (MCF-7) and human colorectal cancer cell line (SW480) were used. Cisplatin (MW300) was used as a positive control. Antibacterial activity was determined by the conventional broth dilution assay. ${ }^{14}$ Six terrestrial pathogenic bacteria M. tetragenus, E. coli, B. cereus, S. aureus, K. rhizophila and B. subtilis were used, and ciprofloxacin was used as a positive control.

\section{ACKNOWLEDGEMENTS}

This work was supported by the National Natural Science Foundation of China (21162009, 31360069 and 21462015), 973 Program, Ministry of Science and Technology of China (Grant no. 2014CB560714).
1. Debbab, A et al. New anthracene derivatives-structure elucidation and antimicrobial activity. Eur. J. Org. Chem. 7, 1351-1359 (2012).

2 Assante, G. \& Nasin, G. Identity of the phytotoxin stemphylin from Stemphylium botryosum with altersolanol A. Phytochemistry 26, 703-705 (1987).

3 Debbab, A. et al. Bioactive metabolites from the endophytic fungus Stemphylium globuliferum isolated from Mentha pulegium. J. Nat. Prod. 72, 626-631 (2009).

4 Teiten, M. H. et al. Anticancer effect of altersolanol A, a metabolite produced by the endophytic fungus Stemphylium globuliferum, mediated by its pro-apoptotic and antiinvasive potential via the inhibition of NF-kB activity. Bioorg. Med. Chem. 21, 3850-3858 (2013).

5 Zhou, X. M. et al. Antibacterial a-pyrone derivatives from a mangrove-derived fungus Stemphylium sp. 33231 from the South China Sea. J. Antibiot. (Tokyo) 67, 401-403 (2014).

6 Zhou, X. M. et al. Bioactive anthraquinone derivatives from the mangrove-derived fungus Stemphylium sp. 33231. J. Nat. Prod. 77, 2021-2028 (2014).

7 Kumagai, M., Suhara., Y., Aoyagi, T. \& Umezawa, H. An enzyme inhibitor panosialin, produced by streptomyces. II. J. Antibiot. (Tokyo) 24, 870-875 (1971).

8 Aoyagi, T., Yagisawa, M., Kumagai, M., Hamada, M. \& Okami, Y. An enzyme inhibitor panosialin, produced by Streptomyces. I. Biological activity, isolation and characterization of panosialin. J. Antibiot. (Tokyo) 24, 860-869 (1971).

9 Stodola, F. H., Weisleder, D. \& Vesonder, R. F. New dialkylresorcinol from Stemphylium majusculum. Photochemistry 12, 1797-1798 (1973).

10 Achenbach, H. \& Kohl, W. Investigations on metabolites of microorganisms, XVIII. The mass spectrometric fragmentation of flexirubin-type pigments. Chem. Ber. 112, 209-217 (1979)

11 Andersen, B. \& Frisvad, J. C. Natural occurrence of fungi and fungal metabolites in moldy tomatoes. J. Agr. Food Chem. 52, 7507-7513 (2004).

12 Jumpathong, J., Abdalla, M. A., Lumyong, S. \& Laatsch, H. Stemphol galactoside, a new stemphol derivative isolated from the tropical endophytic fungus Gaeumannomyces amomi. Nat. Prod. Commun. 5, 567-570 (2010).

13 Scudiero, D. A. et al. Evaluation of a soluble tetrazolium/formazan assay for cell growth and drug sensitivity in culture using human and other tumor cell lines. Cancer Res. 48, 4827-4833 (1988).

14 Pierce, C. G. et al. A simple and reproducible 96-well plate-based method for the formation of fungal biofilms and its application to antifungal susceptibility testing. Nat. Protoc. 3, 1494-1500 (2008). 